\title{
Efek Pemberian Ekstrak Lidah Buaya (Aloe Barbadensis Miller) pada Soket Gigi terhadap Kepadatan Serabut Kolagen Pasca Ekstraksi Gigi Marmut (Cavia Porcellus)
}

\author{
Fatma Yuza*, Ivan Arie Wahyudi**, dan Sri Larnani** \\ *Pendidikan Dokter Gigi, Fakultas Kedokteran Gigi Universitas Gadjah Mada \\ **Bagian Biomedika Kedokteran Gigi Fakultas Kedokteran Gigi Universitas Gadjah Mada \\ JI Denta No 1 Sekip Utara, Yogyakarta; Indonesia, e-mail: ivanocovic@yahoo.com
}

\begin{abstract}
ABSTRAK
Tindakan ekstraksi gigi menyebabkan terjadinya luka sehingga akan melibatkan proses penyembuhan luka pada jaringan. Salah satu tahap penting dari proses penyembuhan luka pasca esktraksi gigi adalah terbentuknya serabut kolagen. Lidah buaya (Aloe barbadensis Miller) mengandung saponin, vitamin $\mathrm{C}$ dan acemannan yang diduga membantu proses pembentukan serabut kolagen. Tujuan penelitian ini adalah untuk mengetahui pengaruh ekstrak lidah buaya terhadap kepadatan serabut kolagen pada proses penyembuhan luka pasca ekstraksi gigi marmut (Cavia porcellus). Lidah buaya yang digunakan berasal dari Sleman, Yogyakarta. Pembuatan ekstrak menggunakan metode maserasi dan pelarut air. Selanjutnya, dua puluh tujuh ekor marmut dibagi ke dalam kelompok kontrol dan kelompok perlakuan. Kelompok perlakuan terdiri dari kelompok ekstrak lidah buaya $45 \%$ dan $90 \%$. Ekstrak lidah buaya sebanyak $0,05 \mathrm{ml}$ diteteskan kedalam soket gigi marmut pasca ekstraksi gigi pada kelompok perlakuan. Soket gigi marmut kelompok kontrol tidak diberi aplikasi zat aktif apapun. Tiga ekor subjek dari masing-masing kelompok dikorbankan pada hari ke-3, 7, dan 14 setelah ekstraksi gigi. Preparat histologis kepadatan kolagen soket gigi marmut diamati dengan menggunakan mikroskop cahaya perbesaran 400x. Analisis data dilakukan dengan menggunakan uji Kruskal-Wallis dan dilanjutkan dengan uji Post Hoc menggunakan uji Mann-Whitney untuk membandingkan kepadatan kolagen antar kelompok pasca ekstraksi gigi marmut. Hasil uji statistik antar kelompok menunjukkan bahwa ekstrak lidah buaya $90 \%$ berpengaruh pada pembentukan serabut kolagen jika dibandingkan dengan kelompok kontrol $(p<0,05)$ pada hari ke-7 pasca ekstraksi gigi marmut. Kesimpulan dari penelitian ini adalah ekstrak lidah buaya $90 \%$ dapat membantu meningkatkan kepadatan serabut kolagen soket gigi hari ke-7 pasca ekstraksi gigi marmut.
\end{abstract}

Maj Ked Gi. Desember 2014; 21(2): 127 - 135

Kata kunci: ekstrak lidah buaya, kepadatan serabut kolagen, penyembuhan luka, marmut

\begin{abstract}
The Effect of Aloe Barbadensis Miller Extract to The Density of Collagen Fibers in The Wound Healing Process after Tooth Extraction of Guinea Pig (Cavia porcellus). Tooth extraction causes wound that would involve wound healing process on tissue. One of the important stages of wound healing process after dental extraction is the formation of collagen fibers. Aloe barbadensis Miller contains saponins, vitamin C and ace mannan that allegedly assist the process of collagen fibers formation. The purpose of this study was to determine the effect of Aloe barbadensis Miller extract to the density of collagen fibers in the wound healing process after tooth extraction of guinea pig (Cavia porcellus). Aloe vera is used in this study came from Sleman, Yogyakarta. Extract is made with maceration method and water as the solvent. Furthermore, twenty-seven guinea pigs were divided into a control group and treatment groups. The treatment groups consisted 45\% Aloe barbadensis Miller extract group and 90\% Aloe barbadensis Miller extract group. Aloe barbadensis Miller extract as much as $0.05 \mathrm{ml}$ dropped into guinea pigs tooth sockets after tooth extraction in the treatment groups. Guinea pig's tooth socket of the control group was not given any active substance. Three guinea pigs of each group were sacrificed on day 3, 7, and 14 after tooth extraction. Histology preparations of guinea pig teeth sockets density of collagen were observed using light microscope 400x magnification. Analyzing data is done by KruskalWallis test followed by Post Hoc test using the Mann-Whitney test for comparing collagen density between groups. Statistically results between groups showed that the extract of $90 \%$ Aloe barbadensis Miller affected the formation of collagen fibers when compared to the control group $(p<0.05)$ on day 7 after tooth extraction of guinea pig. The conclusion of this study was $90 \%$ Aloe barbadensis Miller extract increased the density of collagen fibers from the tooth socket seven days after tooth extraction of guinea pig.
\end{abstract}

Maj Ked Gi. Desember 2014; 21(2): 127 - 135

Keywords: aloe barbadensis miller extract, density of collagen fibers, wound healing, guinea pig 


\section{PENDAHULUAN}

Ekstraksi gigi adalah pengambilan gigi dari soket di dalam tulang. ${ }^{1}$ Cedera pada ekstraksi gigi berarti melibatkan proses penyembuhan luka pada jaringan. ${ }^{2}$ Proses penyembuhan luka setelah ekstraksi gigi diawali dari terisinya soket gigi dengan darah (coagullum). Pengaktifan fibroblas selanjutnya terjadi di dalam jaringan sehingga menyebabkan jumlah sel fibroblas meningkat dan berpengaruh pada produksi fibril. Bagian dari puncak luka ekstraksi gigi selanjutnya akan mengalami pertumbuhan kapiler ke arah tengah serta jaringan granulasi terbentuk. Proses ini dilanjutkan dengan terjadinya epitelisasi dari puncak gingiva pada luka dan jaringan granulasi berubah menjadi jaringan fibrosa yang diikuti dengan terjadinya osifikasi sebagian sehingga kalus terbentuk. ${ }^{3}$

Saat cedera, jaringan ikat akan melewati tahap perbaikan sehingga fibroblas bermigrasi untuk memproduksi jaringan ikat immature yang disebut juga sebagai jaringan granulasi. Serabut kolagen adalah tipe serabut utama dari jaringan ikat yang ditemukan pada tubuh. ${ }^{4}$ Serabut kolagen merupakan protein utama dari matriks ekstraseluler yang berkontribusi pada pemberian kekuatan pada luka. ${ }^{5}$

Perawatan penyembuhan luka juga dapat dibantu dengan menggunakan tanaman herbal selain menggunakan obat-obatan dan bahan kimiawi. Salah satu tanaman yang memiliki potensi besar dalam memberikan manfaat penyembuhan adalah Aloe barbadensis Miller. ${ }^{6}$

Aloe barbadensis Miller atau yang lebih dikenal dengan lidah buaya adalah salah satu genus besar dari 400 spesies. Kandungan kimia alami yang terdapat di dalam lidah buaya diantaranya adalah asam amino, acemannan, enzim, lignin, mineral, mono dan polisakarida, asam salisilat, saponin, sterol dan vitamin. Vitamin C dan E pada lidah buaya dapat meningkatkan ketersediaan biologis dari nutrisi esensial dan zat yang meningkatkan kesehatan. ${ }^{6}$ Menurut Nusgens dkk., ${ }^{7}$ aplikasi topikal vitamin $C$ pada kulit menunjukkan adanya peningkatan mRNA dari kolagen tipe I dan III. Penelitian yang dilakukan pada wanita postmenopause berusia 50-60 tahun menunjukkan adanya peningkatan nilai dari kolagen tipe I dan III dari kulit lengan pada 6 dari 10 orang sukarelawan sehingga dapat diketahui bahwa vitamin $C$ dapat memberikan efek stimulasi. Penelitian sebelumnya menyatakan bahwa senyawa saponin dalam lidah buaya berpengaruh dalam meningkatkan ekspresi prokolagen tipe I yang dilakukan di dalam kultur fibroblas dermal manusia. ${ }^{8}$ Penelitian lain menunjukkan bahwa acemannan yang berasal dari ekstrak Aloe barbadensis Miller secara signifikan mampu meningkatkan ekspresi kolagen tipe I pada sel sementoblas manusia yang diinkubasi selama 24 jam. ${ }^{9}$

Penelitian sebelumnya ${ }^{10}$ menyatakan bahwa sediaan lidah buaya $90 \%$ freeze drying dapat meningkatkan kepadatan serabut kolagen pada luka ekstraksi gigi marmut. Data pada penelitian tersebut didapatkan dari pengamatan serabut kolagen pada preparat histologis soket gigi marmut yang dikorbankan pada hari ke-3 dan ke7. Hasil penelitian tersebut menunjukkan bahwa terdapat perbedaan yang signifikan dari kepadatan serabut kolagen antara kelompok kontrol dan kelompok perlakuan pada hari ke-7. Sampai saat ini belum dilakukan penelitian yang menunjukkan bahwa ekstrak lidah buaya dengan konsentrasi $45 \%$ dan $90 \%$ yang diteteskan ke dalam soket gigi mampu meningkatkan kepadatan serabut kolagen pada luka pasca ekstraksi gigi. Tujuan penelitian ini untuk mengetahui pengaruh ekstrak Aloe barbadensis Miller konsentrasi $45 \%$ dan $90 \%$ terhadap kepadatan serabut kolagen pada proses penyembuhan luka pasca ektraksi gigi marmut (Cavia porcellus).

\section{METODE PENELITIAN}

Penelitian ini sudah mendapat persetujuan dari Komisi Etik Penelitian Fakultas Kedokteran Gigi Universitas Gadjah Mada. Bahan yang digunakan adalah daun lidah buaya yang berasal dari daerah Sleman, Yogyakarta, akuades, ketamin, xylazin, alkohol, larutan fisiologis, PBS formalin, benang resorbable chromic catgut, larutan dekalsifikasi formic acid HCL, xylol, parafin, bahan pengecatan Mallory, bahan mounting (balsam kanada). 
Alat yang digunakan adalah Gelas ukur, beaker glass, neraca analitis, magnetic stirrer, tabung erlenmayer, timbangan digital, corong buchner, kertas saring, cawan porselen, water bath, falcon tube, micropipette, ekskavator, forceps, jarum bedah, needle holder, gunting bedah, pinset, kapas, sarung tangan lateks, masker, mikroskop cahaya.

Pembuatan Ekstrak Lidah Buaya. Daun lidah buaya yang digunakan telah diuji determinasi tanaman sehingga dapat disetujui secara resmi oleh Bagian Biologi Farmasi Fakultas Farmasi Universitas Gadjah Mada bahwa sampel lidah buaya yang digunakan merupakan jenis Aloe barbadensis Miller. Pembuatan ekstrak lidah buaya menggunakan teknik Maserasi. ${ }^{11}$ Daun lidah buaya dicuci dengan air mengalir dan ditimbang. Daun lidah buaya kemudian dibelah menjadi dua bagian dengan menggunakan pisau dan diambil daging bagian dalamnya agar didapatkan gel yang untuk selanjutnya ditimbang dan dikeringkan didalam inkubator dengan suhu $50^{\circ} \mathrm{C}$ selama $72 \mathrm{jam}$. Lidah buaya yang sudah kering ditimbang dan dijadikan serbuk. Serbuk kemudian ditimbang untuk selanjutnya dicampurkan dengan pelarut air dengan suhu $70^{\circ} \mathrm{C}$ sehingga menjadi larutan. Larutan tersebut diaduk dengan menggunakan magnetic stirrer selama 30 menit dan didiamkan selama 24 jam. Larutan disaring dengan menggunakan corong buchner yang pada bagian kepala tabungnya dilengkapi dengan kertas saring. Ampas hasil penyaringan diaduk ulang dengan menambahkan air pada suhu $70^{\circ} \mathrm{C}$ sebanyak $350 \mathrm{ml}$ dan didiamkan selama 24 jam. Larutan lidah buaya selanjutnya disaring dengan menggunakan corong buchner yang telah dilapisi oleh kertas saring sehingga didapatkan filtrat dan ampas hasil penyaringan. Filtrat dimasukkan kedalam cawan porselen dan dikeringkan diatas waterbath. Ampas hasil penyaringan ditambahakan air sebanyak $200 \mathrm{ml}$ serta didiamkan selama 24 jam untuk selanjutnya disaring kembali sehingga didapatkan filtrat ke-2. Kedua filtrat tersebut dicampurkan dan dikeringkan di atas waterbath dengan suhu $70^{\circ} \mathrm{C}$ sehingga diperoleh ekstrak lidah buaya. Ekstrak lidah buaya kemudian ditimbang dan diencerkan dengan air sehingga didapatkan konsentrasi ekstrak 45\% dan $90 \%$ dan dimasukkan kedalam falcon tube.

Sterilisasi ekstrak lidah buaya dilakukan dengan menggunakan metode filtrasi. Filtrasi ekstrak lidah buaya diawali dengan menggunkan membran penyaring berukuran 0,45 mikron. Ekstrak lidah buaya selanjutnya difiltrasi kembali dengan menggunakan membran penyaring berukuran 0,22 mikron. Proses sterilisasi menggunakan membran penyaring berukuran 0,22 mikron tersebut diulangi beberapa kali hingga tidak ada lagi partikel dan mikroba yang tertahan pada membran penyaring.

Pemberian Ekstrak Lidah Buaya pada Marmut. Marmut ditimbang menggunakan timbangan digital kemudian dianestesi menggunakan kombinasi ketamin dan xylazin secara intramuskular. Gigi marmut kemudian diluksasi menggunakan ekskavator dan diekstraksi dengan menggunakan forceps. Soket gigi diirigasi dengan menggunakan larutan fisiologis dan dikeringkan dengan menggunakan cotton pellet. Ekstrak lidah buaya diteteskan ke dalam soket gigi marmut ke dalam soket gigi marmut sebanyak $0,05 \mathrm{ml}$ (berdasarkan pre-penelitian) dengan menggunakann micropipette. Soket gigi kemudian dijahit dengan menggunakan jarum bedah dan benang resorbable chromic catgut. Marmut kemudian dikorbankan pada hari ke-3, 7, dan 14 pasca ekstraksi gigi dan dilakukan pembuatan preparat histologis untuk diamati kepadatan kolagen yang terbentuk dengan menggunakan mikroskop cahaya perbesaran 400x pada enam lapang pandang.

\section{HASIL PENELITIAN}

Penilaian kepadatan serabut kolagen pada preparat histologis soket gigi marmut dengan pewarnaan Mallory dilakukan dengan menggunakan mikroskop cahaya perbesaran 400x. Data yang diperoleh pada penelitian ini berupa data kuantitatif berskala ordinal. Nilai modus dari kepadatan serabut kolagen soket gigi marmut pada kelompok kontrol, ekstrak lidah buaya $45 \%$, dan ekstrak lidah buaya $90 \%$ terhadap masing-masing hari pengamatan dapat dilihat pada Gambar 1. 


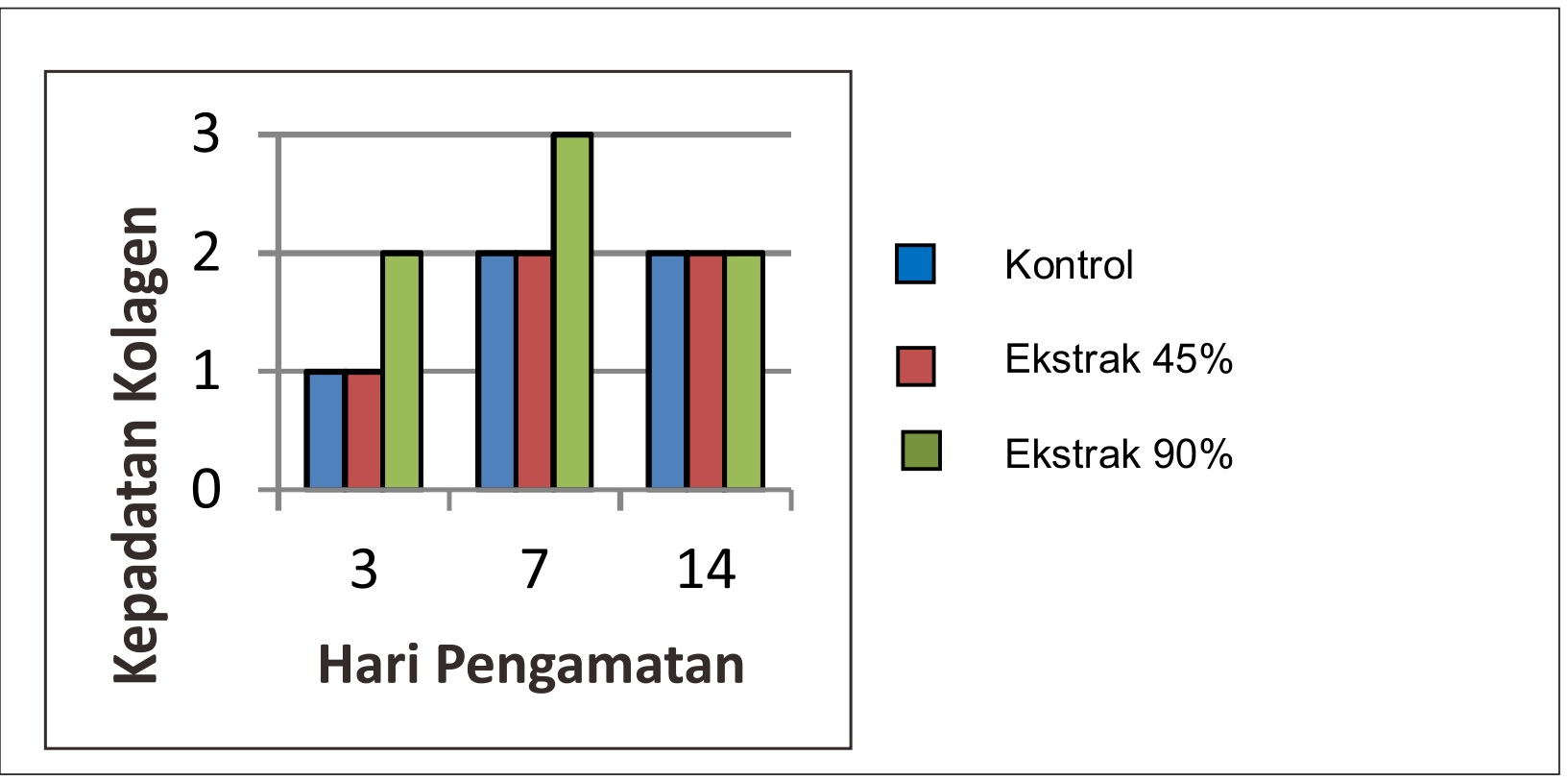

Gambar 1. Diagram hasil penelitian kepadatan kolagen soket gigi marmut pasca aplikasi kelompok perlakuan.

Uji Kruskal-Wallis digunakan untuk mengetahui perbedaan kepadatan kolagen antar kelompok pasca ekstraksi gigi marmut. Uji KruskalWallis dengan nilai $p>0,05$ didapatkan dari hasil pengamatan pada hari ke-3 $(p=0,102)$ dan ke-14 $(p=0,304)$ pada masing-masing kelompok sehingga dapat diketahui bahwa tidak terdapat perbedaan kepadatan serabut kolagen yang bermakna antar kelompok pada hari ke-3 dan ke-14 pasca ekstraksi gigi. (Tabel 1). Uji Kruskal-Wallis dengan nilai $p<0,05$ didapatkan dari hasil pengamatan pada hari ke-7 $(p=0,044)$ pada kelompok kontrol, ekstrak lidah buaya $45 \%$, dan ekstrak lidah buaya $90 \%$ sehingga diketahui bahwa terdapat perbedaan kepadatan serabut kolagen pada hari ke-7 pada kelompok kontrol, ekstrak lidah buaya $45 \%$, dan ekstrak lidah buaya 90\% (Tabel 1).

Tabel 1. Hasil uji Kruskal-Wallis antar kelompok pada kepadatan serabut kolagen soket gigi pasca ekstraksi gigi marmut.

\begin{tabular}{ccc}
\hline $\begin{array}{c}\text { Hari } \\
\text { Pengamatan }\end{array}$ & Chi-Square & p \\
\hline 3 & 4,571 & 0,102 \\
7 & 6,231 & 0,044 \\
14 & 2,381 & 0,304 \\
\hline
\end{tabular}

Untuk mengetahui kelompok yang mempunyai perbedaan kepadatan serabut kolagen yang bermakna pada hari ke-7, maka dilakukan analisis Post Hoc dengan menggunakan uji Mann-Whitney. Uji Mann Whitney dilanjutkan untuk mengetahui perbandingan masing-masing kelompok kontrol dengan ekstrak lidah buaya konsentrasi $45 \%$ maupun $90 \%$ pada hari ke-7 (Tabel 2).

Tabel 2. Hasil uji Mann-Whitney antarkelompok perlakuan pada pengamatan kepadatan kolagen hari ke-7 pasca ekstraksi gigi marmut.

\begin{tabular}{lcc}
\hline Jenis Perlakuan & $\begin{array}{c}\text { Mann- } \\
\text { Whitney U }\end{array}$ & p \\
\hline Kontrol - Ekstrak 45\% & 1,000 & 0,099 \\
Kontrol - Ekstrak 90\% & 0,000 & 0,034 \\
Ekstrak 45\% - Ekstrak & 0,500 & 0,068 \\
$90 \%$ & & \\
\hline
\end{tabular}

Hasil uji statistik antara kelompok kontrol dengan kelompok ekstrak lidah buaya 90\% pada hari ke-7 adalah $p=0,034$ (Tabel 2). Berdasarkan nilai uji Mann-Whitney yang dilakukan tersebut dapat diketahui bahwa terdapat perbedaan kepadatan serabut kolagen yang bermakna antara kelompok kontrol dengan kelompok ekstrak lidah buaya $90 \%$ pada hari ke-7 pasca ekstraksi gigi marmut. 


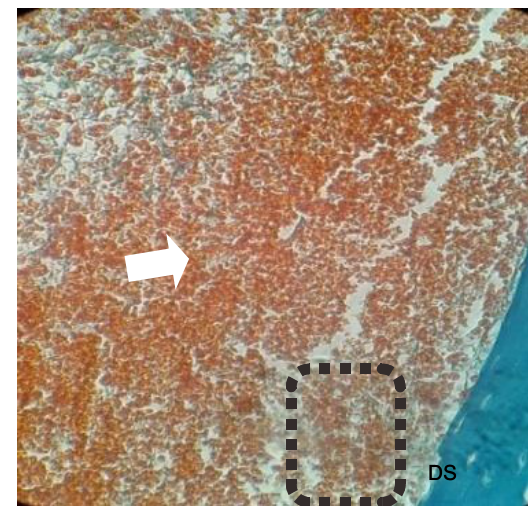

(A)

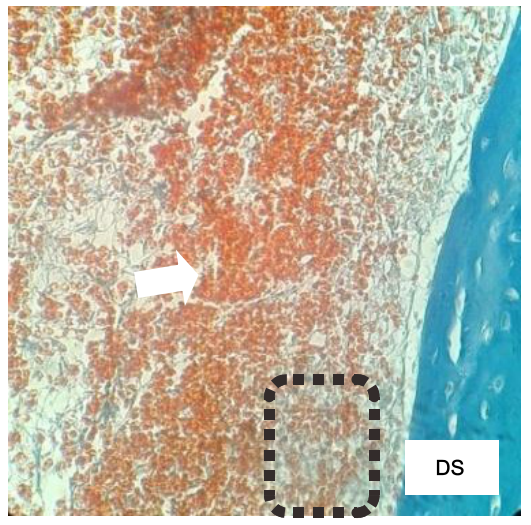

(B)

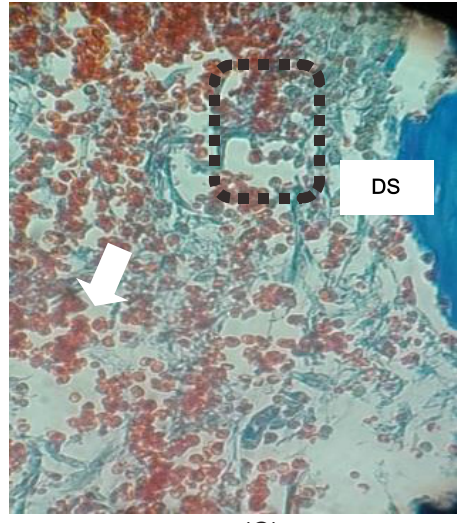

(C)

Gambar 2. Gambaran histologis kolagen (kotak hitam) 3 hari pasca ekstraksi gigi. (A) kontrol, (B) ekstrak lidah buaya 45\% dan (C) ekstrak lidah buaya $90 \%$, (DS) dinding soket. Anak panah putih menunjukkan jaringan granulasi. Perbesaran 400x. Serabut kolagen tampak tipis pada gambar A,B, dan C.

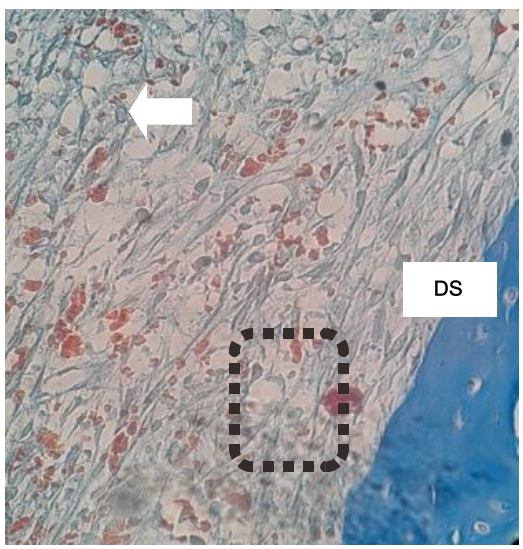

(A)

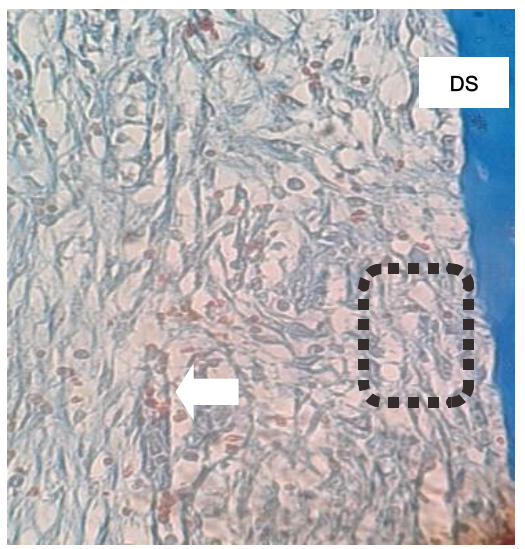

(B)

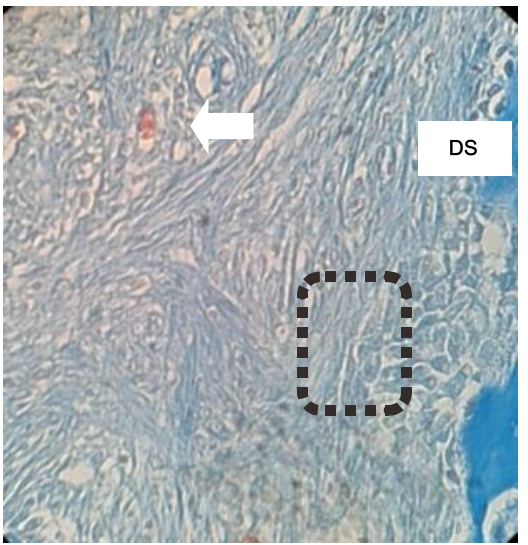

(C)

Gambar 3. Gambaran histologis kolagen (kotak hitam) 7 hari pasca ekstraksi gigi. (A) kontrol, (B) ekstrak lidah buaya 45\% dan (C) ekstrak lidah buaya 90\%, (DS) dinding soket. Anak panah putih menunjukkan jaringan granulasi. Perbesaran 400x. Serabut kolagen pada gambar $\mathrm{C}$ tampak lebih tebal dibandingkan gambar $\mathrm{A}$ dan $\mathrm{B}$.

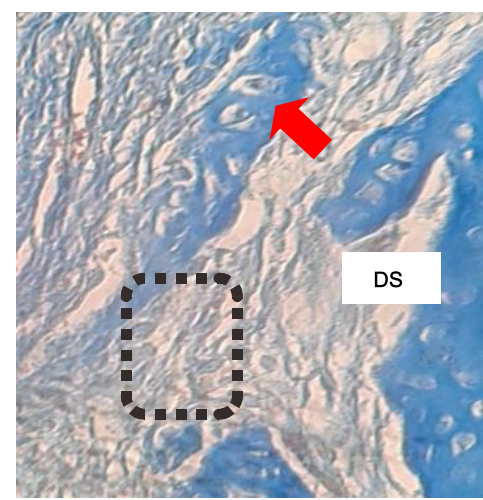

(A)

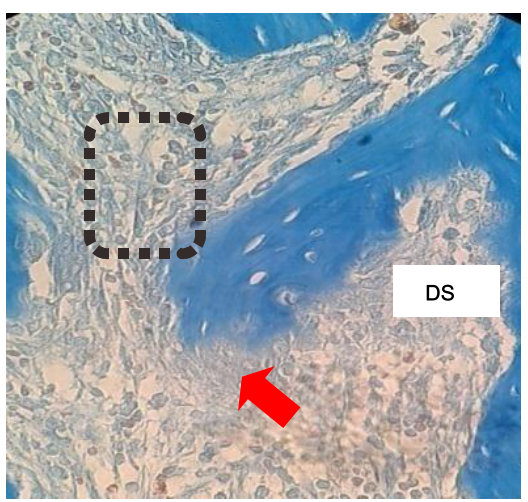

(B)

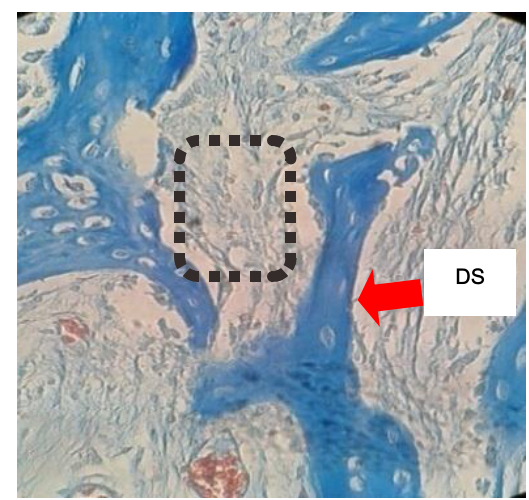

(C)

Gambar 4. Gambaran histologis kolagen (kotak hitam) 14 hari pasca ekstraksi gigi. (A) kontrol, (B) ekstrak lidah buaya 45\% dan (C) ekstrak lidah buaya 90\%, (DS) dinding soket. Anak panah merah menunjukkan matriks tulang. Perbesaran 400x. Serabut kolagen pada gambar $\mathrm{C}$ tampak lebih tipis dibandingkan gambar $\mathrm{A}$ dan $\mathrm{B}$. 


\section{PEMBAHASAN}

Lidah buaya merupakan tanaman fungsional karena semua bagian dari tanaman dapat dimanfaatkan untuk mengobati berbagai penyakit. Lidah buaya telah dikenal sejak ribuan tahun silam dan umumnya dapat digunakan sebagai penyembuh luka. ${ }^{12}$ Lidah buaya diketahui mampu meningkatkan ekspresi prokolagen tipe I secara intra dan ekstra seluler pada dermis manusia. ${ }^{13}$ Prokolagen dibentuk dalam retikulum endoplasma secara intraseluler dan akan diubah menjadi kolagen secara ekstraseluler. ${ }^{14}$ Kolagen adalah salah satu protein ekstraseluler yang terdapat didalam semua jaringan dan organ. Kolagen menyediakan kerangka yang memberikan bentuk dan kekuatan pada jaringan dan merupakan protein yang paling penting bagi manusia. ${ }^{15}$ Kolagen merupakan bagian kunci didalam proses penyembuhan luka. ${ }^{2}$

Gambaran hasil pengamatan histologis kepadatan kolagen pada preparat soket gigi marmut pasca pencabutan gigi dan aplikasi kelompok kontrol, ekstrak lidah buaya $45 \%$, dan ekstrak lidah buaya $90 \%$ dapat dilihat pada Gambar 2, 3 dan 4 .

Serabut kolagen tipis dengan banyaknya jaringan granulasi pada soket gigi dapat ditemukan dari kelompok ekstrak lidah buaya $45 \%$, ekstrak lidah buaya $90 \%$, dan kontrol pada hari ke-3 pasca ekstraksi gigi (Gambar 2). Terdapat karakteristik infiltrasi sel inflamasi pada hari ke-3 pasca ekstraksi gigi. ${ }^{16}$ Secara statistik, tidak terdapat perbedaan yang bermakna antar kelompok pada hari ke-3 pasca ekstraksi gigi marmut. Hasil ini sesuai dengan penelitian sebelumnya mengenai efek lidah buaya $90 \%$ freeze drying terhadap kepadatan serabut kolagen pada hari ke-3 dan 7 pasca ekstraksi gigi marmut. ${ }^{17}$ Penelitian tersebut menunjukkan bahwa tidak terdapat perbedaan yang signifikan antar kelompok pada hari ke-3 dikarenakan pembentukan serabut kolagen baru dimulai pada hari ke-3.

Fibroblas mulai menginvasi area cedera pada hari ke-3 setelah dirangsang oleh produk makrofag. ${ }^{2}$ Aktifasi makrofag sebagai respon dari pelepasan chemoattractans dari jaringan yang cedera, platelet, neutrofil, limfosit, dan bakteria diketahui dapat membantu proliferasi fibroblas dan meningkatkan sintesis kolagen. Makrofag dapat melepaskan faktor-faktor pertumbuhan seperti PDGF (platelet derived growth factor) dan TGF- $\beta$ (transforming growth factor $\beta$ ) yang merangsang proliferasi sel pada penyembuhan luka. PDGF memiliki kemampuan aktifasi fibroblas dan TGF- $\beta$ diketahui dapat menginduksi deposisi kolagen.

Jaringan granulasi tampak lebih sedikit pada hari ke-7 pasca ekstraksi gigi marmut. Serabut kolagen yang lebih tebal mulai mendominasi soket gigi marmut pada kelompok ekstrak lidah buaya $90 \%$ dibandingkan dengan hari ke-3 pasca ekstraksi gigi marmut (Gambar 3). Menurut penelitian sebelumnya pada pengamatan akhir minggu pertama pasca ekstraksi gigi, alveolus tampak dipenuhi oleh jaringan ikat immature yang banyak dengan adanya kandungan fibroblas. ${ }^{17}$ Fibroblas mampu berproliferasi dan lebih aktif mensintesis komponen matriks sebagai respon terhadap cedera. ${ }^{18}$ Proliferasi fibroblas melalui pembelahan sel berlangsung setiap 18 hingga 20 jam. Fungsi utama dari aktifasi fibroblas pada area cedera adalah untuk memproduksi kolagen, elastin dan proteoglikan. ${ }^{2}$

Analisis statistik menunjukkan bahwa terdapat perbedaan kepadatan serabut kolagen yang bermakna pada hari ke-7 pasca ekstraksi gigi pada masing-masing kelompok. Hasil pengamatan kepadatan kolagen menunjukkan bahwa terdapat perbedaan yang bermakna pada kelompok ekstrak lidah buaya $90 \%$ jika dibandingkan dengan kelompok kontrol. Uji tersebut membuktikan bahwa ekstrak lidah buaya $90 \%$ berpengaruh dalam membantu pembentukan serabut kolagen pada hari ke-7 pasca ekstraksi gigi marm ut.

Hasil pengamatan pada hari ke-14 menunjukkan telah terbentuknya matriks tulang pada soket gigi dengan penurunan kepadatan serabut kolagen pada kelompok ekstrak lidah buaya 90\% (Gambar4). Berdasarkan uji statistik, tidak terdapat perbedaan kepadatan kolagen yang terjadi antar kelompok pada hari ke-14. Tulang adalah jaringan ikat yang mengalami mineralisasi. ${ }^{19}$ 
Serabut kolagen merupakan bagian dari matriks organik tulang yang terbenam dalam substansi dasar kaya proteoglikan. ${ }^{8}$ Sekitar $90 \%$ dari matriks organik tulang adalah kolagen tipe I. ${ }^{19}$

Pada pembentukan tulang baru, serabut kolagen memiliki diameter yang berbeda-beda dan susunan kurang teratur yang memberikan struktur kusut atau seperti anyaman keranjang pada tulang. Tulang immature tersebut disebut sebagai anyaman tulang (woven bone). Glikoprotein yang berhubungan dengan tulang seperti osteopontin, osteonektin, bone sialoprotein (BSP), osteokalsin dan fibronektin memainkan peran penting dalam pembentukan tulang dan mineralisasi. ${ }^{19}$ Penelitian sebelumnya menyatakan bahwa anyaman tulang dapat diamati pada 2 hingga 4 minggu setelah ekstraksi gigi. ${ }^{20}$

Penelitian lain menunjukkan bahwa terdapat peningkatan hidroksi prolin yang berdampak pada peningkatan kandungan kolagen pada kelinci yang diberi aplikasi gel lidah buaya pada hari ke-7 jika dibandingkan dengan kelompok tanpa perlakuan. ${ }^{21}$ Vitamin $C$ yang terkandung di dalam lidah buaya berperan sebagai kofaktor dari hidroksilasi prolin yang dibutuhkan dalam sintesis dan sekresi kolagen. Hidroksilasi membutuhkan substrat, molekul $\mathrm{O}_{2}$, askorbat (vitamin $\mathrm{C}$ ), $\mathrm{Fe}^{2+}$ dan $\alpha$-ketoglutarat untuk mengubah setiap mol prolin menjadi hidroksi prolin dan setiap mol $\alpha$-ketoglutarat menjadi suksinat. ${ }^{22}$

Senyawa saponin yang terkandung di dalam lidah buaya dapat meningkatkan level protein prokolagen tipe I seluler yang direduksi oleh sinar UV. ${ }^{23,}{ }^{24}$ Saponin adalah kelompok glikosida yang merupakan gula larut air. ${ }^{25}$ Glikosida terbentuk dari kondensasi antara kelompok hidroksil dari residu monosakarida dan senyawa aglikon. ${ }^{26}$ Sintesis kolagen selain membutuhkan hidroksilasilasi prolin juga membutuhkan glikosilasi hidroksil didalam molekul prokolagen. ${ }^{27}$ Glikosilasi protein berfungsi untuk membentuk glikoprotein yang dapat merubah stabilitas dan fisik dari protein. ${ }^{28}$

Acemannan merupakan salah satu polisakarida yang terdapat di dalam lidah buaya. ${ }^{6}$ Penelitian sebelumnya menunjukkan bahwa monosakarida yang terkandung di dalam acemannan terdiri dari
97\% manosa dan 3\% glukosa. ${ }^{28}$ Gula manosa diketahui akan berikatan dengan reseptor manosa dan akan memberi pengaruh secara langsung terhadap aktifasi TGF- $\beta$ karena bentuk aktif TGF- $\beta$ perlu diubah dari bentuk tidak aktifnya sebelum dilepaskan dan melakukan fungsi biologisnya ${ }^{28}$. TGF- $\beta$ berperan dalam menginduksi deposisi kolagen. ${ }^{2}$

\section{KESIMPULAN}

Berdasarkan penelitian yang telah dilakukan, maka dapat diambil kesimpulan bahwa pemberian estrak lidah buaya dengan konsentrasi 90\% mampu meningkatkan kepadatan serabut kolagen yang lebih tinggi dibandingkan kelompok kontrol dan ekstrak lidah buaya $45 \%$ pada hari ke-7 pasca ekstraksi gigi. Perlu penelitian lebih lanjut mengenai kemampuan ekstrak lidah buaya dalam membantu penyembuhan luka soket gigi melalui faktor-faktor penyembuhan luka lainnya seperti angiogenesis, epitelisasi dan osteogenesis. Penelitian lebih lanjut mengenai jenis dan konsentrasi efektif dari zat aktif yang terkandung didalam ekstrak lidah buaya sehingga dapat membantu proses penyembuhan luka juga perlu dilakukan.

\section{DAFTAR PUSTAKA}

1. Balaji SM. Text Book of Oral and Maxillofacial Surgery. New Delhi: Elsevier; 2007. p. 211. Diakses dari http://books.google.co.id/books ?Balaji.,+2007,+Textbook+of+Oral+and+Maxi Ilofacial+Surgery diunduh 4 Februari 2013.

2. Gottrup F, Jensen SS, Andreasen JO. Wound Healing Subsequent to Injury. In: Andreasen JO, Andreasen FM, Andersson L, eds, Textbook and Color Atlas of Traumatic Injuries to the Teeth. $4^{\text {th }}$ ed. Oxford: Blackwell Publishing Ltd.; 2007. p. 1,4, 6, 23, 26, 32, 41.

3. Švermová D. Teeth Extraction. In: Dostálová $T$ and Seydlová $M$, eds, Dentistry and Oral Diseases. Praha: Grada Publishing; 2010.p. 74. Diakses dari http://google.co.id/ books? Švermová.+D.,+ 2010+Teeth+ Extraction,+in+Dostálová.diunduh 12 Februari 2013. 
4. Balogh MB, Fehrenbach MJ. Dental Embryology, Histology, and Anatomy. $2^{\text {nd }}$ ed. Philadelphia: Elsevier Inc.; 2006. p. 112-3.

5. Panda $\mathrm{H}$. Aloe vera Handbook Cultivation, Research Findings, Products, Formulations, Extraction and Processing. New Delhi: Asia Pacific Business Press Inc.; 2003. p. 16, 40. Diakses dari http://books.google.co.id/books ? id=zqwL83POxWoC \& printsec=frontcover\& $\mathrm{dq}=$ panda+aloe+vera+handbook\&hl=id\&sa= $X \& e i=$ rOOUZjqNsSzrAeh-oBY\&redir_esc=y. diunduh 13 Februari 2013.

6. Barcroft A, Myskja,A. Aloe vera Nature's Silent Healer. London: BAAM Publishing Ltd.;2003. p. $1,27,28,30,33,34,38,39,46$. Diakses dari http://books.google.co.id?Barcroft+Aloe+vera nature's+silent+healer. diunduh 13 Februari 2013.

7. Nusgens $B V$, Humbert $P$, Rougier A, Colige AC, Haftek M, Lambert CA, Richard A, Creidi P, Lapière M. Topically Applied Vitamin C Enhances the mRNA Level of Collagens I and III, Their Processing Enzymes and Tissue Inhibitor of Matrix Metalloproteinase 1 in the Human Dermis. Journal of Investigative Dermatology. 2001; 116(16): 853-859.

8. Moon HI, Chung JH, Lee JK, Zee OP. Tritepenoid saponin from Viola hondoensisW. Becker et $\mathrm{H}$ Boss. and their effect on MMP1 and type I procollagen expression. Archives Pharmacal Research. 2004; 7(27): 730-733.

9. Sahawat D, Khantasuwan S, Sangvanich P, Takata T, Kitagawa M, Thunyakitpisal P. Acemannan Induces Cementoblast Proliferation, and Mineral Deposition. Journal of Medicinal Plants Research. 2012; 6(23): 4069-4076.

10. Arijani E, Khoswanto C. The Use of $90 \%$ Aloe vera Freeze Drying as The Modulator of Collagen Density On Extraction Socket of Incicivus Cavia cobaya. Dental Journal. 2008; 41(2): 74-6.

11. Irshad $S$, Butt $M$, Younus $H$. In-Vitro Antibacterial Activity of Aloe Barbadensis Miller (Aloe Vera). International Research Journal of Pharmaceuticals. 2011; 2(1): 59-64.
12. Furnawanthi I. Khasiat dan Manfaat Lidah Buaya Si TanamanAjaib. Jakarta: Agromedia Pustaka;2007. p. , 1, 3, 4, 10. Diakses dari http://books.google. co.id/bookfurnawanthi+khasiat+manfaat diunduh 13 Februari 2013.

13. Cho S, Lee $\mathrm{S}$, Lee MJ, Lee $\mathrm{DH}$, Won $\mathrm{CH}$, Kim SM, Chung JH. Dietary Aloe Vera Supplementation Improves Facial Wrinkles and Elasticity and It Increases the Type I Procollagen Gene Expression in Human Skin in vivo. Ann Dermatol (Seoul). 2009; 1(21): 6-11.

14. Glitz D. Protein Shyntesis: Translation and Posttranslational Modifications. In: Devlin TM, eds, Textbook of Biochemistry With Clinical Correlations. $7^{\text {th }}$ ed. Philadelphia: John Wiley and Sons Inc.; 2011. p. 232, 244.

15. Schultz RM. In: Devlin TM, eds, Textbook of Biochemistry With Clinical Correlations. $7^{\text {th }}$ ed. Philadelphia: John Wiley and Sons Inc.; 2010. p. 103.

16. Reis-Filho CR, Silva ER, Martins AB, Pessoa FF, Gomes PVN, Araújo MSC, Miziara MN, Alves JB. Demineralised Human Dentine Matrix Stimulates The Expression of VEGF and Accelerates The Bone Repair In Tooth Sockets of Rats. Archieve of Oral Biology. 2012; 5(57): 469-479.

17. Yugoshi LI, Sala MA, Brentegani LG, Carvalho TLL. Histometric Study of Socket Healing after Tooth Extraction in Rats Treated with Diclofenac. Brazil Dental Journal. 2002; 13(2): 92-6.

18. Fawcett DW. Buku Ajar Histologi (A Textbook of Histology) (terj.). $2^{\text {nd }}$ ed. Jakarta: EGC; 2002. p. 122-3, 125, 132, 178.

19. Berkovitz BKB, Moxham BJ, Linden RWA, Sloan AJ. Master Dentistry. $3^{\text {th }}$ ed. London: Elsevier Ltd.; 2011. p. 221.

20. Trombelli L, Farina R, Marzola A, Bozzi $\mathrm{L}$, Lindhe J. Modeling and Remodeling of Human Extraction Sockets. Journal of Clinical Periodontology. 2008; 35: 630-9.

21. Subramanian $S$, Kumar DS, Arulselvan $P$. Wound Healing Potential of Aloe vera Leaf Gel Studied in Experimental Rabbits. Asian Journal of Biochemistry. 2008; 1(2): 178-185. 
22. Rodwell VW. Catabolism of Proteins and of Amino Acid Nitrogen. In: Murray RK, Granner DK, Mayes PA, Rodwell VW, eds, Harper's Illustrated Biochemistry. $26^{\text {th }}$ ed. New York: Mc Graw-Hill Companies Inc.; 2007. p. 244.

23. Arunkumar $S$, Muthuselvam M. Analysis of Phytochemical Constituents and Antimicrobial Activities of Aloe vera L. Against Clinical Pathogens. World Journal of Agriculture Sciences. 2009; 5(5): 572-6.

24. Hwang YP, Kim HG, Choi JH, Han EH, Kwon K, Lee YC, Choi JM, Chung YC, Jeon TC, Jeong HG. Saponin From The Roots of Platycodon grandiflorum Supress Ultraviolet A-Induced Matrix Metalloproteinase-1 Expression Via MAPKs and NF-KB/Ap-1-Dependent Signaling in HaCaT Cells. Food and Chemical Toxicology. 2011; 12(49): 3374-82.

25. Hoffmann D. Medical Herbalism : The Science and Practice of Herbal Medicine. New York: Healing Arts Press; 2003. p. 74-5. Diakses dari http://google.co.id/books?hoffman+medical+ herbalism. diunduh 13 Februari 2013.

26. Mayes PA, Bender DA. Carbohydrates of Physiologic Significance. In: Murray RK, Granner DK, Mayes PA, Rodwell VW, eds, Harper's Illustrated Biochemistry. $26^{\text {th }}$ ed. New York: Mc Graw-Hill Companies Inc.; 2003. p. 105.

27. Murray RK, Keeley FW. The Extracellular Matrix. In: Murray RK, Granner DK, Mayes PA, Rodwell VW, eds, Harper's Illustrated Biochemistry. $26^{\text {th }}$ ed. New York: Mc Graw-Hill Companies Inc.;2003. p. 535, 537.

28. Lee JK, Lee MK, Yun YP, Kim Y, Kim JS, Kim YS, Kim K, Han SS, Lee CK. Acemannan purified from Aloe vera induces phentpic and functional maturation of immature dendritic cells. International Immunopharmacology. 2001; (1): 1275-84.

29. Garg HG, Longaker MT. Scarless Wound Healing. New York: Marcel Dekker, Inc.; 2005. p. 219. 